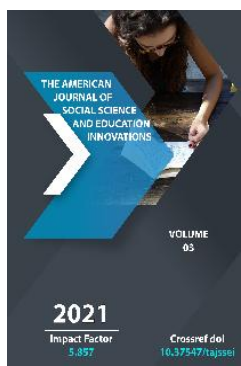

\title{
Similarities And Distinctive Features Of Uzbek, Russian And English Phrases
}

Navruza Aliyeva

Teacher Of Ferghana State University, Uzbekistan

Journal Website:

http://theamericanjour

nals.com/index.php/taj

ssei

Copyright: Original content from this work may be used under the terms of the creative commons attributes 4.0 licence.

\section{ABSTRACT}

This article discusses the terms of similarities and differences between languages and their significance in the linguistic environment; the types of collocations are also investigated by analyzing their use in multi-system languages and the ways of their translation into English, Russian and Uzbek are examined. Research is carried out on the types of phrasemes in languages and equivalents are presented, as well as analogs when translated and used in contexts. As a result, certain formulas are identified for the formation of equivalent collocations in languages.

\section{KEYWORDS}

Isomorphism, allomorphism, classification of collocations, phrasemes, contrastive analysis, predictability in translation, non-idiomatic collocations.

\section{INTRODUCTION}

Exploring phraseological units in terms of Fedulenkova identifies the following features their similarities (isomorphism) T.N. of 
phraseological units as phraseological universals:

1) Asymmetric dualism of phraseological units

2) Structural discreteness of phraseological units

3) Semantic coherence of phraseological units

4) The type of dependence of the components of phraseological units

5) The type of variance of the component composition of phraseological units

6) The entry of a phraseological unit into the language system in the aggregate of its variants

7) Biplanarity of structural and semantic modeling of phraseological units

8) Clipping of phraseological units as a way of tertiary phraseological nomination

9) Structural parallelism of a phraseological unit with its genetic prototype

10) The hierarchy of links in the functioning of phraseological units.

Isomorphism (conformity) is opposed by "allomorphism", which testifies to the heterogeneity of the structure of linguistic units that constitute this level.

In English phraseology, one of the first attempts to create a structural classification of English idiomatic expressions belongs to L. Smith, who collected an extensive collection of phraseological units that went beyond all existing collections of idioms at that time. In his classification, L. Smith, taking into account the peculiarities of the English language, singles out phraseological units of an adverbial nature, which are combinations of prepositions with nouns and adjectives, for example, for good - навсегда; as well as combinations of verbs with postpositions, which he calls, phraseological verbs, for example, keep down - подавлять, держать в подчинении [1].

Collocations in English are a multifaceted and complex linguistic phenomenon. Any phenomenon, in addition to the definition, presupposes and requires the allocation and description of the ways of its presentation. Linguists believe that one of these methods is the classification of collocations, which makes it possible to obtain a more accurate and scientifically literate picture of this complex phenomenon through the systematization of varieties of linguistic signs [2]. The term "collocation" is insufficiently developed and studied in Russian and Uzbek linguistics, therefore, for the linguistic characteristics of this type of set expressions, it is advisable to consider various classifications of collocations according to several principles with the translation of all examples into Russian and Uzbek languages.

The linguistic interpretation of M. Benson's collocations is to understand them as idioms [3], which follows from the classification he proposed:

1. Non-composite - the meaning of collocation does not follow from the meaning of its parts. Or the meaning is completely different from the free combination (as in the case of idioms such as kick the bucket (сыграть в ящиколамдан ўтмоқ).

2. Non-replaceable - parts of collocation cannot be replaced with other words, even if in the context they have the same meaning. For example, white wine (белое вино - оқ вино) cannot be replaced with other words denoting shades of white (желтовато-белое вино - сарғимтир вино). 
3. Immutable - collocations that cannot be freely changed with the help of additional lexical material or with the help of grammatical rules (transitions). This is especially true for fixed expressions such as idioms. The transition from the singular to the plural can create an incorrectly constructed (inconsistent) idiom in Russian, for example, in the phrase "people as poor as church mice" (люди, бедные как церковные мыши). То adequately convey the meaning of this collocation in the Uzbek language, one needs to pay attention to the ethnolinguistic features of the idiom. From this point of view, the meaning of this expression should be conveyed using such phrasemes as "ўта даражада қашшоқ, қўл учида тирикчилик ўтказишади”.

The classification of collocations by M. Benson has much in common with the classification of phraseological units by V.V. Vinogradov, who draws attention to the semantic cohesion of mergers and unities.

Linguist A. Cowie drew attention to the fact that the meaning of a collocation consists of the meanings of the words included in it. The collocation a 'broken window' is classified as an open collocation due to the fact that the meaning of this phrase is the sum of the meanings of two independent words included in it. On the other hand, closed collocations are distinguished by the fact that one of the words is not used in its usual meaning as, for example, in the phrase 'to jog one's memory' (напомнить, заставить вспомнить - эсга солиш, эслашга мажбур қилиш), the verb to jog does not mean to run - бежать, yugurish.

Despite the lack of complete unity of opinion in defining the principles of classification, it is possible to highlight common features of the description and systematization of collocations in English, phrasemes in Russian and Uzbek languages: in contrast to free phrases, where each word can be replaced by another word without significantly changing the meaning of the entire phrase, and also, unlike idiomatic expressions - phrases in which the semantic meaning does not come from the meaning of individual (separate) constituent parts, collocations are stable, repetitive, non-idiomatic phrases.

Analysis of scientific literature shows that English collocations and Russian and partially Uzbek PUs are built according to certain formulas:

a) Adjective + noun (adjective + noun), for example: a huge profit; high earnings; a heavy rain; lasting happiness; a strong sun; побочный эффект - ножўя таъсир; свежий хлеб - юмшоқ нон; исключительный случай - истисноли ходиса;

b) Noun + noun (noun + noun), for example: a pocket calculator; a personal safety; email bounces; a key factor; монитор компьютера - копьютер монитори; личная безопасность - шахсий мухофаза; бонус электроннной почты электрон почта бонуси; ключевой фактор - асосий омил;

c) Noun + verb (noun + verb), for example: the economy boomed; prices rise; time passes; time goes by; экономика расцветает - иқтисодиёт гуллабяшнайди; цены растут - нарх-наво кўтарилмоқда;

d) Verb + adverb (verb + adverb), for example: smile proudly - шествовать вальяжно - беписандлик билан юриш;

e) Adverb + adjective (adverb + adjective), for example: absolutely wrong абсолютно неправильно - мутлақо хато; highly unlikely; utterly ridiculous; blissfully happy - крайне маловероятно хақиқатда узоқ; совершенно нелепо - 
мутлақо бемаънилик; блаженно счастлив - бахтдан масрурлик.

In Russia, the most popular was the structural and semantic classification of A.V. Kunin [4].

The structural classification presented in the works of A.V. Kunin, includes the following types of stable combinations of the English language:

- Nominative phraseological units, within which substantive phraseological units (crocodile tears), adjective phraseological units (as swift as thought), adverbial phraseological units (out of a clear sky), verbal phraseological units (play with loaded dice) are distinguished;

- Interjection PU (by the Lord Henry);

- $\quad$ PU with modal value (at any price);

- Communicative phraseological units, which include proverbs and sayings (that is a horse of another color, there is no smoke without fire).

Depending on the nature of the leading component, phraseological combinations are subdivided into substantive, verbal, adjective and adverbial.

The structure of substantive idioms includes fully or partially rethought phraseological units with the structure of a phrase and completely rethought phraseological units with a partially predicative structure. The main types of rethinking are metaphorical and metonymic rethinking: a dog in the manger, a big gun, a snake in the grass, a bitter pill to swallow, a break in the clouds, a blind hand, an eagle eye, a heart of gold.

Adjective phraseological units include such units "in which an adjective ... or, less often, a participle acts as a definition." The first component of adjective comparisons is usually used in its basic literal meaning, and the second performs an amplifying function: as brave as a lion, pretty as picture, as weak as water, ugly as sin, brown as berry, sober as a judge, as hard as a bone, free as air, certain as mud, fierce as a tiger.

Adverbial phraseological units are considered, functionally correlated with an adverb and function as circumstances and answering the questions "In which way?", "How?" and Where?". They represent the most variegated category in terms of composition and variety of components. These phraseological units are united by a common meaning of a secondary feature: they express the characteristic of an action or the degree of a qualitative characteristic of an object, respectively, combined with verbs and with adjectives.

Stylistic differentiation of phraseological units includes "evaluative-emotional-expressive features that are acquired by phraseological units due to their preferred and even exclusive use in those rather than other spheres and areas of human communication".

This type of classification, based on the concept of N.M. Shansky, provides the following varieties of phraseological units of the English language:

- Interstyle;

- Colloquial and everyday;

- Bookstores;

- Archaisms and historicisms.

Interstyle phraseological turns have no stylistic coloring (lowered or sublime) and can be actively used in all styles of oral and written speech. For the most part, these phraseological units are devoid of generalized metaphorical meaning, for example: in any case, from time to time, at any cost, minute by minute, at every step, entirely and completely, etc. Interstyle phraseological units are able to 
enter into synonymous relations with stylistically colored phraseological units: from time to time - " «иногда; и нет-нет да и"(colloquial); with might and main - "изо всей силы; со всей решимостью", thick and thieves спаянные крепкой дружбой, закадычные друзья", bright as a button "чистенький, нарядный", to give soul "умереть".

Colloquial - everyday phraseological turns are stable combinations of words, mainly or exclusively used in oral speech. They have a figurative character and are distinguished by expressive-stylistic coloring: affectionate, abusive, ironic, contemptuous, playful, etc.: as cross as a bear - злой как пес, a gay cat прожигатель жизни, a fair cow - неприятный тип, мошенник, негодяй, as blind as a bat - с очень плохим зрением, (as) nervous as a cat очень нервный, to work like a racing dog очень упорно работать [5].

Book phraseological turns are stable combinations of words, mainly or exclusively used in written speech. They differ in the sphere of use (written speech) and "increased" expressive-stylistic coloring (bookish, solemn, pathetic, poetic, etc.). They are used in newspaper-journalistic, officialbusiness styles of speech, as well as in fiction. For example, Sodom and Gomorrah - содом и гоморра, cast pearls before swine - метать бисер перед свиньями, the apple of one's еуе - зеница ока, a wolf in sheep's clothing волк в овечьей шкуре, forbidden fruit запретный плод, the four corners of the earth - четыре стороны света.

Archaic phraseological units, like words, fall into two groups: phraseological unitshistoricisms and phraseological unitsarchaisms.

Phraseological historicisms are phraseological phrases that have fallen out of active use in connection with the disappearance of the corresponding phenomenon of reality. For example: to sail under false colors - плавать под чужим флагом.

Phraseological archaisms are phraseological units that have fallen out of active use due to their displacement by other stable combinations or individual words that turned out to be more suitable for expressing the corresponding concepts. For example, on the knees of the Gods - одному богу известно, and back number - отсталый человек.

It is necessary to note the appearance of new words and phrases in the Oxford English Dictionary and Cambridge Dictionary:

Awesomesauce - Something Very Good something that you are incredibly happy about.

Safe space - a place or environment in which a person belonging to any of the minorities feels comfortable and does not lend himself to criticism and discrimination.

Beardo - bearded; type of people who wear a beard: hipsters, intellectuals, etc.

To have its moment - to be popular and fashionable for a short period of time.

Social gifting - a good deed or charity work that you do instead of buying someone a gift.

Food desert - an area where there is no access to healthy food.

Ecological grief - a sense of deep sadness and responsibility due to climate change and environmental problems.

Techno-optimism - the belief that technology will change the world for the better.

Micro-scheduling - planning every minute of your day.

And also we should add expressions related to the coronavirus, Covid-19. 
Covidiot - a person who neglects security measures during quarantine or buys all the necessary goods without thinking about others. Another expression on this topic - beer bug - a slang term for coronavirus, which comes from the name of Mexican beer.

Nevuary - February 3oth, that is, a day that never comes.

Rofling - rolling on the floor laughing.

WOAT - Worst Of All Time - the opposite of GOAT (Greatest Of All Time).

Itchy feet - an irresistible desire to travel.

Sasha has itchy feet. I think it's hard for her to stay at home.

The above opinions are largely related to translation activities. The translation of classical works, in scientific terms, can be called the interpretation of the text of work of art is often associated with the rethinking of phraseological units [6]. Such problems often arose when translating the Baburname treatise. As an example, various versions of the translation into English of the following passage are given: "Ушбу тарихда у шанба куни, рамазон ойининг тўртида Умар Шайх Мирзо жардин кабутар ва кабутархона била учуб, шунқор бўлди. Ўттиз тўққуз ёшар эди" [7].

In the above sentence, the separately written phraseological unit "учуб, шунқор бўлди" in the translation of Leiden-Erskine sounds like this: On Monday, the 4th of the month of Ramzan, of the year that has been mentioned, Omer-Sheikh Mirza was precipitated from the top of the steep, with his pigeons, and pigeonhouse, and took his flight to the other world. He was then in the thirty-ninth year of his age.

This passage, translated by S. Beveridge, sounds like this: on Monday, Ramzan 4, (June 8th.) 'Umar Shaikh Mirza flew, with his pigeons and their house, and became a falcon.
And in the translation of W. Texton as follows: On Monday, the fourth of Ramadan of this year (June 8, 1494), Umar-Shaykh Mirza toppled into the ravine, with his doves and dovecote and gave up the ghost. He was thirty nine years old.

Leiden J. and Erskine V. translated the treatise, trying to convey the meaning. S. Beveridge used mostly tracing paper in her translations, and the method of transliteration was also observed. V. Texton, under the influence of the author's deep philosophical and spiritual experiences, was able to better convey the semantic meanings of phraseological units in comparison with the translations of phraseological units made by $\mathrm{S}$. Beveridge. V.Texton used more idioms as phraseological units [8].

\section{REFERENCES}

1. Smith L.P. Phraseology of the English language Text. / L.P. Smith / trans. from English M.: 1979. - 189 p.

2. Iordanskaya L.N., Melchuk I.A. Meaning and compatibility in the dictionary. - M., Publishing house: Languages of Slavic cultures, 2007 - 672 p.

3. Benson Morton. The structure of the collocational dictionary. International Journal of Lexicography 2.89. pp. 1-14.

4. Kunin A. V. Course of phraseology of modern English. - M.: "High school", 1996. - 380 p; Kunin A.B. Phraseology of Modern English: The Experience of a Systematic Description. Moscow: International Relations Publishing House, 1972c. - 288 p.

5. Izotova A.A. Playing on English phraseological units in speech. 2nd edition, rev. -M.: Book House "LIBROKOM", 2013. -96p. 
6. Chinenova L.A. English phraseology in language and speech. - Publishing. 2nd, rev. -M.: Book House "LIBROKOM", 2009. $-101 \mathrm{p}$.

7. Zahiriddin Muhammad Bobur. Boburnoma. -Tashkent.: "Sharq", 2002 P.99. 335 p.

8. Teshaboeva Z. Q. Phraseological units in English translations of "Boburnoma" and their national-cultural features. (PhD) Tashkent - 2017. 34 p. 